\title{
CURRENT CHALLENGES OF SOCIAL RESPONSIBILITY BEST PRACTISE IN FOODSTUFF PRODUCTION AND DISTRIBUTION CHAIN: FOCUS ON CEE COUNTRIES
}

\author{
Lukáš Poláček , Jan Vavřina ${ }^{2}$,Josef Polák ${ }^{3}$ \\ ${ }^{1}$ Research staff member, Department of Business Economics, Mendel University in Brno, Zemédělská 1, 61300 Brno \\ Czech Republic. Phone No. +420545132625, E-mail address xpolace3@node.mendelu.cz \\ ${ }^{2}$ Research assistant, Corresponding author, Department of Business Economics, Mendel University in Brno, Zemédělská \\ 1, 61300 Brno, Czech Republic, E-mail address: jan.vavrina@mendelu.cz \\ ${ }^{3}$ Research assistant, Department of Economics and Management, The College of Regional Development and Banking \\ Institute - AMBIS, a.s., E-mail address: josef.polak@ambis.cz
}

Received 0110 2021; Accepted 13102021

\begin{abstract}
Corporate social responsibility in the food production and distribution sector in Europe is currently mainly linked to the activities of food banks. Food banks in the current form provide their services free of charge, however, these activities are closely associated with support from public budgets and volunteering. Currently, there is a growing tendency to revise the current funding scheme and the overall provision of food banks' activities, as well as the efficiency aspects of their operation. It is, therefore, necessary to identify the essential aspects of the social responsibility framework, in particular from the side of participating entities as donors to food banks. The new situation calls for a revision of food banks' operation schemes, including supportive voluntary intentions within the business environment. Specifically, the importance of the social responsibility of business entities can be seen in their inclusive assistance in the recent global COVID-19 crisis. This article aims at the identification of financial aspects behind voluntary donations to food banks, using the exploratory approach, namely via identification of major differences between voluntary donors and the respective industry benchmark in the field of financial criteria, focusing on Central and Eastern European countries (CEE). It was employed a methodological approach for testing independent observed samples to compare selected financial performance indicators' mean values, using a two-sample T-test for equal and non-equal variances. Subsequently, a dynamic decomposition of observed financial performance indicators is conducted for a revision of the existence of mutual correlations. Differently from the main areas of interest of identified previous research on food banks' activities, our effort is focusing on business entities in the role of food banks' stakeholders. Corporate micro-financial data of foodstuff donors in Central and Eastern European countries according to their accessible annual reports and lists of donors to foodbanks are employed. Authors thus point out, based on provided empirical evidence, a need for a more inclusive type of attitude to food banks' operations from the foodstuff production and distribution chain and its participants.
\end{abstract}

Keywords: corporate finance, food banks, production and distribution chain, social responsibility. JEL Classification: Q18, D22, C55.

\section{Introduction}

The concept of food banks originated in the 1990s in the United States and the United Kingdom. However, the presented concept faced many challenges and developmental changes, such as the growing share of consumption of unhealthy industrially produced food, or the long-term dependence of food bank clients on the type of social services they provide. Wainwright, Buckingham, \& Wainwright (2018) find the identified benefits of food banks in the United Kingdom precisely

Copyright (C) 2021 Author(s), published by Vytautas Magnus University. This is an open access article distributed under the terms of the Creative Commons Attribution Non-Commercial 4.0 (CC BY-NC 4.0) license, which permits unrestricted use, distribution, and reproduction in any medium provided the original author and source are credited. The material cannot be used for commercial purposes 
concerning their position outside the structure of public social services.

The global crisis caused by the expansion of COVID-19 affects all countries of the world in different ways. As in any crisis, deeper budgetary implications can be expected for low-income groups, as well as an increase in the number of social cases caused by the loss of business and employment. The European Union declares its efforts to combat the crisis, but at the same time, each state decides on the appropriate steps in possible international coordination.

Given the specific approaches, the state of food banking in the UK can be used to learn from the pros and cons of their system, while respecting the specificities of national systems for the functioning of social policies in Central and Eastern European countries (CEE). Limitations of social responsibility side of food bank activities in CEE countries can be identified mainly in a diverse scope of problem areas, including on one hand financing of this type of activities regarding the need for meeting hygienic standards within food donations, and on the other hand, lack of intentions to take part in food donations schemes by a certain type of business entities (e. g. Gracjasz, \& Grasseni, 2020; Nikolov, 2021; Petrovici,. \& Gorton, 2005).

Food banks can be seen as independent public interest institutions by helping to reduce food waste and also by contributing to corporate social responsibility in relation to tackling poverty and the related nutritional needs of the population concerned (e.g. Caraher \& Furey, 2018; Lipinski et al., 2013; Soon et al., 2016). Although food is provided free of charge to these banks, their operation is mostly dependent on subsidies from the state budget. Specifically for example the case of the Czech Republic, these are operating and investment subsidies, especially from the budget chapter of the Ministry of Agriculture (Ministry of Agriculture of the Czech Republic, 2019). Thus, there is a growing tendency to revise the current scheme of financing the activities of food banks and also the efficiency of their operations (e.g. González-Torre, Lozano, \& Adenso-Díaz,
2017; Kuang \& Chou, 2017; Ministry of Agriculture of the Czech Republic, 2019). The growing trend in the use of food banks is associated with changes in the living standards of the population and reductions in public budgets, which, among others, provide empirical evidence on the link between living standards and the use of food banks (Loopstra, \& Lalor, 2017).

This article aims at an exploratory insight into financial aspects behind voluntary donations to food banks, via the identification of differences between voluntary donors and the respective industry benchmark in the field of corporate financial indicators. It covers the years 2009-2017, i.e. period that includes the worldwide financial crisis, followed by the period of economic recession and consequently economic growth renewal. The scientific problem copes with a possible existence of differences between voluntary donors and the respective industry benchmark in the field of selected key financial performance indicators. Authors employ the empirical analysis approach on the accessible micro-financial data behind business activities of typical corporate food donor's sample in selected CEE countries, to reveal possible similarities and differences in their financial performance development within the observed period. Consequently, the hypothesis testing of equality of the selected financial performance indicators is conducted to compare a sample of business food donors with respective evidence on the industry average values.

Differently from the main areas of interest in the identified previous research and studies on food banks' activities, our contribution is focusing on business entities in the role of food banks' stakeholders. Our findings can address a possible rethink of attitude to foodstuff donors groups such as producers and distributors, regarding the scope of their inclusion within food banking schemes and systems at regional and national levels.

\section{Methods}

Authors use an explorative approach for identifying major financial aspects behind 
corporate social responsibility intentions within voluntary donations to food banks by business entities with a focus on CEE countries and the United Kingdom as a traditional country with activities of food banks. However, due to a lack of microdata on business activities of agri-food complex businesses based in the United Kingdom, only sectoral data of Eurostat could be employed for the case of the United Kingdom. We provide on one hand the industry overview, covering main indicators of business activity and its cost-efficiency side, on the other hand then a more focused insight into business activities of voluntary food bank donors to compare them with an identified industry average data. The industry overview of CEE countries is based on accessible secondary financial data, using the database Orbis of Bureau van Dijk (nonavailability of needed microdata on businesses based in the United Kingdom). The sample size for the respective observed industry and country is provided in Table 1 . Specifically, according to accessible information of particular national/regional food banks on their voluntary donors it was identified a sample of businesses within EU NACE (statistical classification of economic activities) divisions $01,10-11$, and 46 (see the next paragraph for more details on classification of business activities of voluntary donors).

Table 1. Industry sample volumes regarding EU NACE classification of appropriate divisions of observed businesses in CEE countries for the period of years 2009 and 2017

\begin{tabular}{|l|c|c|c|}
\hline \multirow{2}{*}{ Country } & \multicolumn{3}{|c|}{ Industry benchmark sample group size per EU NACE division } \\
\cline { 2 - 4 } & 01 & $10-11$ & 46 \\
\hline Bulgaria & 1447 & 870 & 1048 \\
\hline Croatia & 619 & 721 & 296 \\
\hline Czech Republic & 1951 & 743 & 401 \\
\hline Estonia & 889 & 252 & 251 \\
\hline Hungary & 3627 & 1527 & 1546 \\
\hline Latvia & 564 & 266 & 279 \\
\hline Lithuania & 27 & 81 & 83 \\
\hline Poland & 866 & 1055 & 717 \\
\hline Romania & 5015 & 3582 & 2244 \\
\hline Slovakia & 1533 & 558 & 421 \\
\hline Slovenia & 65 & 145 & 116 \\
\hline
\end{tabular}

The secondary corporate financial data of voluntary donors to food banks were retrieved from the ORBIS database of Bureau van Dijk (Bureau van Dijk, (C2019). The searching strategy was employed as follows. The sample of businesses is specifically retrieved under announcements of food banks concerning their voluntary donors. These announcements were prevailingly provided by food banks based in the Czech Republic, Hungary, Poland, and Slovakia, which are also the member states of the Visegrad Group. Authors assume the normality of data due to a sampling procedure for identifying active food producers and the samples size per se. In addition, an expectation about the constitution of homogenous groups of businesses in the Visegrad 4 member countries can be supported e.g. by findings of Ivanova \& Cepel (2018), who consider economies of the Visegrad 4 member countries as similar at a general level. Observed businesses within relevant EU NACE industry divisions with consolidated financial statements were excluded from the sample to diminish distortion in observation of selected financial performance indicators.

EU NACE industry divisions covered:

- 01 Plant and animal production excluding specific activities at subdivisions 01.6 (support activities to agriculture and post-harvest crop activities) and 01.07 (hunting and 
trapping of wild animals and related activities),

- 10-11 Manufacture of food products and non-alcoholic beverages excluding specific activities at subdivisions 10.9 (manufacture of industrial feed) and 11.01-11.06 (manufacture of alcoholic beverages and related products),

- 46.3 Wholesale of food and nonalcoholic beverages (further on denoted as EU NACE division 46).

Selected financial indicators for the respective economic performance analysis are focusing on the efficiency aspects of placing production on market. The efficiency of placing production on the market for the sample of business entities was measured by the indicator cost of sales and its respective dynamic decomposition of operating expenditures and sales. The aforementioned efficiency indicator is enumerated for respective annual microfinance business data as follows. Cost of sales as the proportion of operating expenditures to volume of sales. Operating expenditures are derived as the margin of operating turnover and operating profit before interests and taxation.

Dynamic decomposition of constitutes of the cost of sales indicator, namely operating expenditures and sales, is conducted via the fixed base and chain index approach.

The sample volume of voluntary donors to food banks, which constitute homogenous groups according to the EU NACE classification and appropriate industry benchmarks, can be seen in Table 2 .

Table 2. The Visegrad 4 member countries' sample volumes regarding EU NACE classification of appropriate divisions of observed businesses in years 2009 and 2017

\begin{tabular}{|l|c|c|c|c|c|c|}
\hline \multirow{2}{*}{ Country } & \multicolumn{2}{|c|}{ Voluntary donors sample group size } & \multicolumn{3}{c|}{ Industry benchmark sample group size } \\
\cline { 2 - 7 } & 01 & $10-11$ & 46 & 01 & $10-11$ & 46 \\
\hline Czech Rep. & 4 & 11 & 7 & 1951 & 743 & 401 \\
\hline Hungary & - & 10 & 22 & 3627 & 1527 & 1546 \\
\hline Poland & - & 10 & 5 & 866 & 1055 & 717 \\
\hline Slovakia & - & 5 & 2 & 1533 & 558 & 421 \\
\hline
\end{tabular}

There is employed also a statistical verification of the significance of differences between voluntary donors to food banks and respective industry benchmarks to support the results of the given research problem. Statistical verification of partial findings is conducted by a two-sided two-sample T-test in the alternates for equal and unequal variances based on a two-sample variance F-test. Subsequently, a dynamic decomposition of selected financial indicators is employed for the revision of the existence of mutual dependencies by means of correlation analysis. There are constituted the following partial hypotheses to be assessed:

- Hypothesis 1A: There are no significant differences in financial measures of efficiency in placing production on market between voluntary donors and industry benchmark within observed countries regarding EU NACE division 01 Plant and animal production;
- Hypothesis 1B: There are no significant differences in financial measures of efficiency in placing production on market between voluntary donors and industry benchmark within observed countries regarding EU NACE divisions group 10-11 Manufacture of food products and non-alcoholic beverages;

- Hypothesis 1C: There are no significant differences in financial measures of efficiency in placing production on market between voluntary donors and industry benchmark within observed countries regarding EU NACE divisions 46.3 Wholesale of food and nonalcoholic beverages;

- Hypothesis 2A: There is no dependency between the development of operating expenditures and sales as partial financial efficiency measures, considering voluntary donors and 
industry benchmarks within observed countries in EU NACE division 01 Plant and animal production;

- Hypothesis 2B: There is no dependency between the development of operating expenditures and sales as partial financial efficiency measures, considering voluntary donors and industry benchmarks within observed countries in EU NACE divisions group 10-11 Manufacture of food products and non-alcoholic beverages;

- Hypothesis 2C: There is no dependency between the development of operating expenditures and sales as partial financial efficiency measures, considering voluntary donors and industry benchmarks within the Visegrad 4 member countries in EU NACE divisions 46.3 Wholesale of food and non-alcoholic beverages.

Software Statistica 13 was employed for conducting the computational procedures.

\section{Results and discussion}

The development of producer prices in the primary and secondary sectors can be regarded as an important factor that is influencing the need for food banks' services provision. Figure 1 depicts the development of respective price levels within the agri-food industry in CEE countries in comparison with the EU after the year 2010. It can be stated a two-wave growth of producer prices in both observed sectors after the year 2010 and 2015 for the food and beverage manufacturing industry, 2016 respectively for the primary agricultural production. The highest increase in producer prices in both observed sectors was identified beside Romania in Hungary, namely the average growth rate from the year 2010 base exceeding $16 \%$ for the food and manufacturing industry, $20 \%$ for primary agricultural production, respectively. In Romania then the average growth rate exceeded $17 \%$ for the food and manufacturing industry production and nearly $18 \%$ average growth rate for agricultural producers' prices. On the other hand, the lowest average growth rate for the food and manufacturing industry production was identified for the observed period in Slovenia with a $5 \%$ value. The lowest average growth rate for agricultural producers' prices in the observed period was then identified in Croatia with its value of $6 \%$.
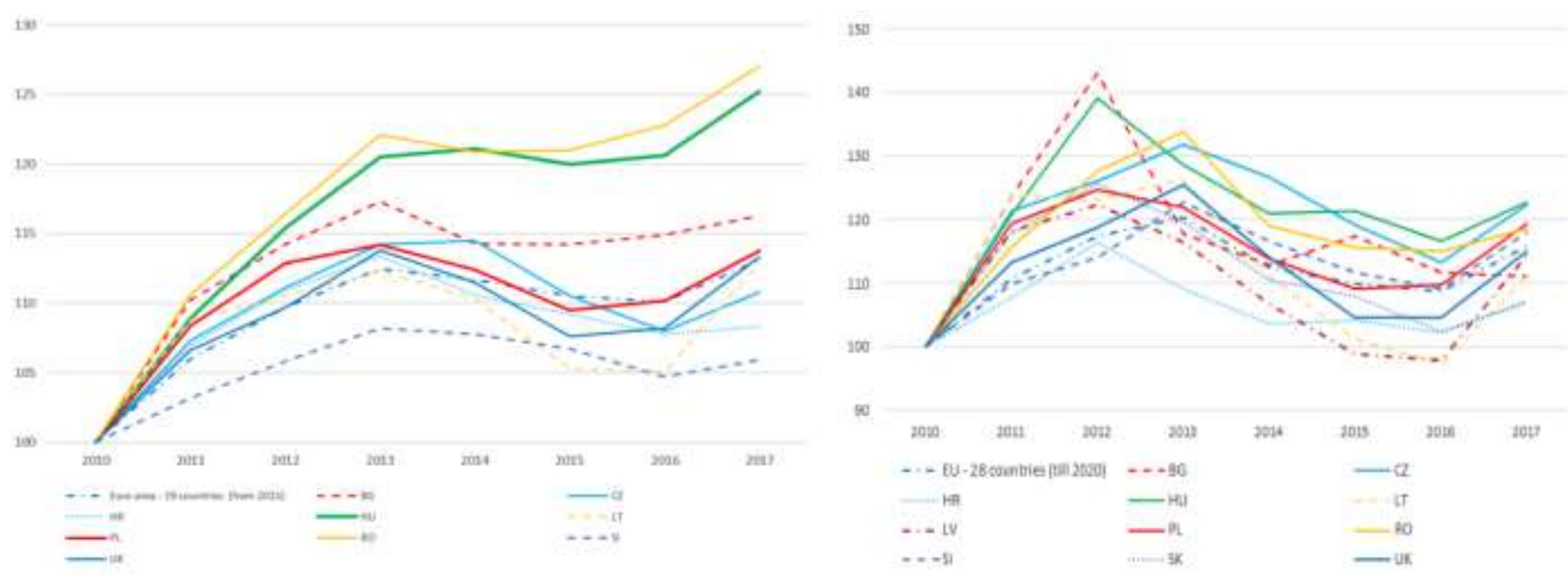

Figure 1. Base index $(2010=100)$ of producer prices development in food and beverages manufacturing industry (left graph) and overall agricultural producer prices development in CEE countries and the UK (right graph)

*(Own work using data of Eurostat (2021)) Data for Slovakia regarding the food and beverages manufacturing industry is not available. 
Further analysis regarding the development of the increasing prices trend within the agri-food complex is conducted via indicator cost of sales among CEE countries and selected EU NACE sectors' divisions, using the identified industry samples. In detail, the development of the indicator cost of sales for the EU NACE division 01-agricultural production reveals its highest level for the case of the Czech Republic, followed by Latvia and Estonia after the year 2012. Development that was observed for the EU NACE division 1011 is distinguishing among CEE countries in the case of Romania with the highest average value of the indicator cost of sales during the whole period of years 2009-2017. This finding among the industry sample is consistent with the aforementioned level of producer prices development within the food and beverages manufacturing industry in Romania. On the other hand, the lowest level of observed cost of sales indicator was identified within the industry NACE division 10-11 for Bulgaria, despite its above-average development of producer prices in that industry. EU NACE division 46 development then reveals a prevailing stagnation of the observed indicator cost of sales among all observed CEE countries. Namely, the variation from the mean value of the indicator cost of sales is ranging from $0,1 \%$ (observed in Bulgaria) to only 0,7 $\%$ (observed in Romania).

The empirical insight into the area of food waste diminishing schemes due to accessible information covering also information on business voluntary donors is focusing on the Visegrad 4 member countries, i.e. Czech Republic, Hungary, Poland, and Slovakia. Namely, the identified voluntary donors to food banks as legal business entities, which were active in EU NACE industries' divisions 01, 10-11, and 46. Conducted analysis reveals on an explanatory base identifiable differences of selected financial indicators reported by business voluntary donors to food banks in comparison with the industrial averages. Figure 2 depicts a comparison of the aforementioned sample groups of business entities' donors to food banks with respective industries' benchmark of indicator cost of sales within the Visegrad 4 member countries. Respective partial results for the Visegrad 4 member countries are as follows. Voluntary donors in the Czech Republic are represented at the EU NACE industry division 01 by businesses with on average lower cost of sales values within the observed period, namely values differing in average for more than 10 PPS. Other observed business donors to food banks within respective EU NACE industry divisions in the Czech Republic are not identified as significantly varying from industry average values. More precisely, mean values of indicator cost of sales is exceeding $97 \%$ for EU NACE industry divisions 10-11, mean values of that indicator for EU NACE industry division 46 is then exceeding $98 \%$ for the sample of the group of voluntary donors. 


\section{sciendo}

Management Theory and Studies for Rural Business and Infrastructure Development eISSN 2345-0355. 2021. Vol. 43. No. 4: 442-456

Article DOI: https://doi.org/10.15544/mts.2021.40
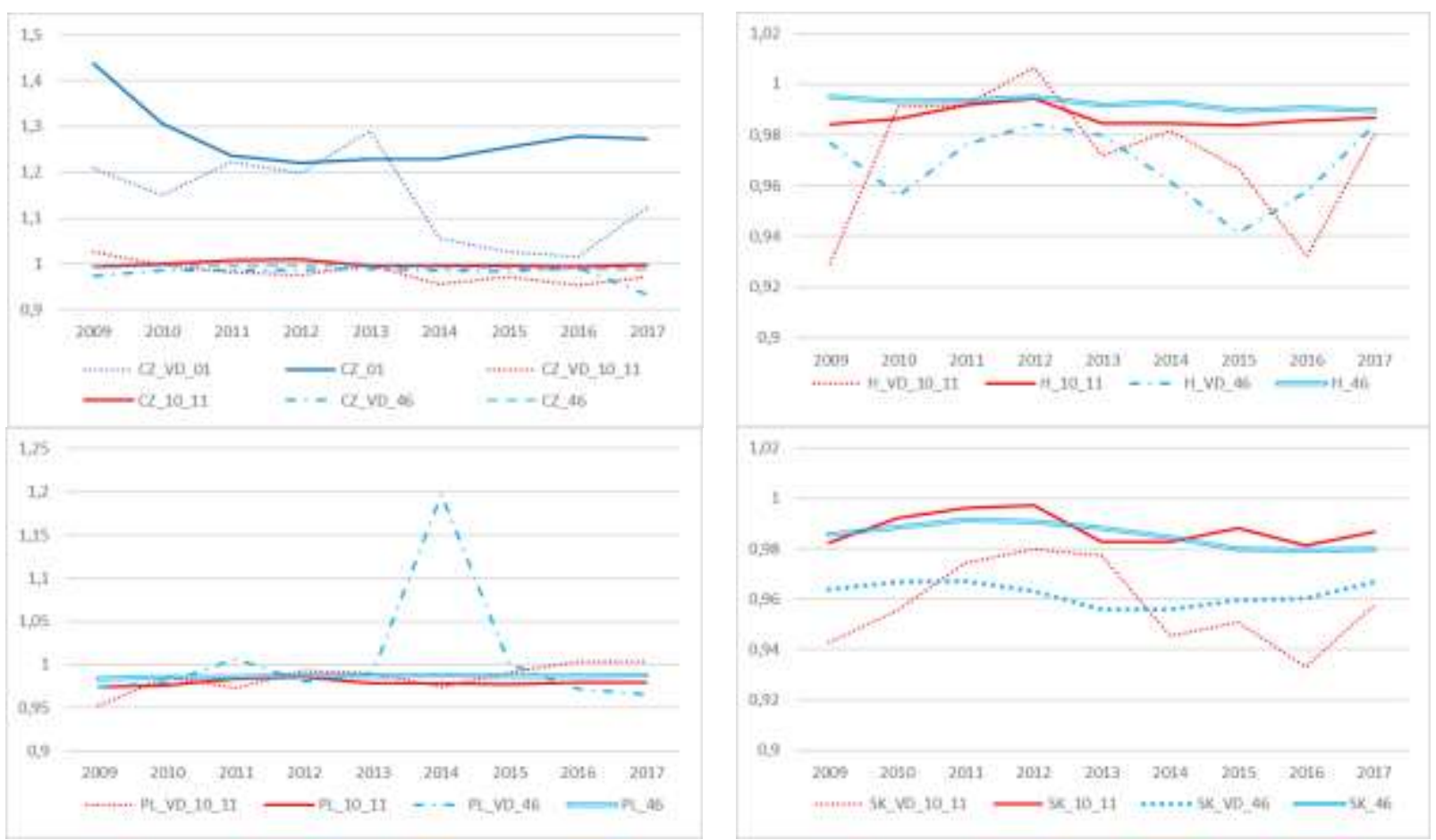

Figure 2. The development of cost of sales indicator, comparing voluntary donors (VD) with industry average in the observed industries regarding EU NACE divisions within the Visegrad 4 countries - Czechia (upper left graph), Hungary (upper right graph), Poland (lower left graph), Slovakia (lower right graph).

*Voluntary donors to food banks were not identified for EU NACE industry division 01 in Hungary, Poland and Slovakia.

Voluntary donors to food banks in Hungary are represented within the EU NACE industry divisions $10-11$ by businesses, which have also similar values of indicator cost of sales during the observed period of years, namely low volatility of the cost of sales indicator in both observed industries. In addition, it was identified a neglect lower level of cost of sales among voluntary donors to food banks in Hungary, specifically after the year 2012, but with the higher volatility of this indicator in comparison with the observed industry average (variation from average values of the cost of sales indicator at $2.5 \%$ for industry divisions EU NACE 10-11 and $1.5 \%$ for industry division EU NACE 46, respectively). A similar development was observed also among voluntary donors to food banks in Poland and Slovakia. It was influenced by a strong identified increase in the cost of sales in Poland in the year 2014 and by a fall in sales among a sample group of food donors within EU NACE industry division 46. That excessive decrease in sales in the year 2014 is deduced to be in direct connection with notified food safety problems of food production that originated in Poland.

An analytical dynamic decomposition of the indicator cost of sales was conducted via year-on-year indices of development of indicators operating expenditures and sales as a comparison of voluntary donors to food banks with the industry average (see depiction in Figures 3 and 4). It was identified the highest volatility of operating expenditures among donors to food banks within the Visegrad 4 member countries regarding EU NACE industry division 10-11 for the observed donors' sample group in Poland. Namely, the variation coefficient reaches nearly a $12 \%$ difference from a mean year-on-year development of operating expenditures in 
Poland, within the period of years 2009-2017. In addition, this sample group of food donors based in Poland also reaches the highest average growth of operating expenditures among the other Visegrad 4 member countries' sample groups within the observed period of years 2009-2017, namely nearly $13 \%$. A similar development was identified also for the sample group of donors to food banks for the EU NACE industry division 46. That sample group of donors based in Poland reported both the highest volatility within the development of operating expenditures and its highest average growth rate among other observed the Visegrad 4 member countries (variation coefficient overreaching $16 \%$, the average

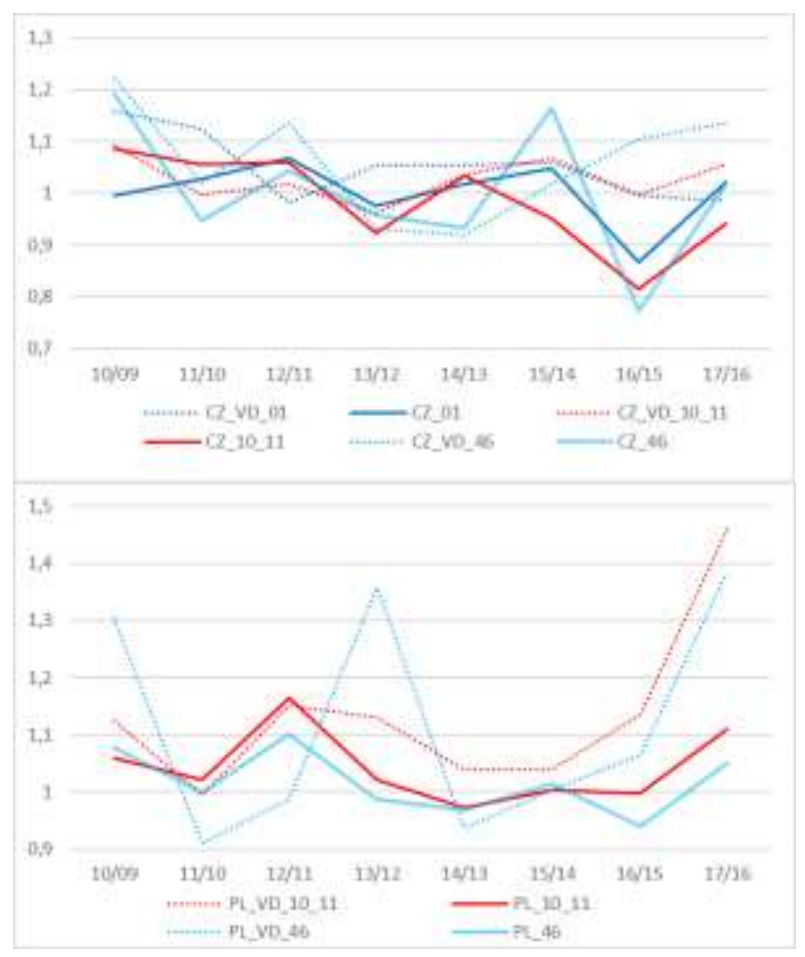

growth rate of operating expenditures above 10 $\%)$. On the other hand, the most stable development of operating expenditures within sample groups of donors to food banks in the Visegrad 4 member countries was identified for EU NACE divisions 10-11 among donors based in Hungary (variation coefficient lower than $2 \%$, average growth rate $3.4 \%$ ). In addition, the most stable development of operating expenditures for sample groups of donors to food banks active in EU NACE division 46 was identified in Slovakia (variation coefficient lower than $2 \%$, the average growth rate of operating expenditures up to $10 \%)$.

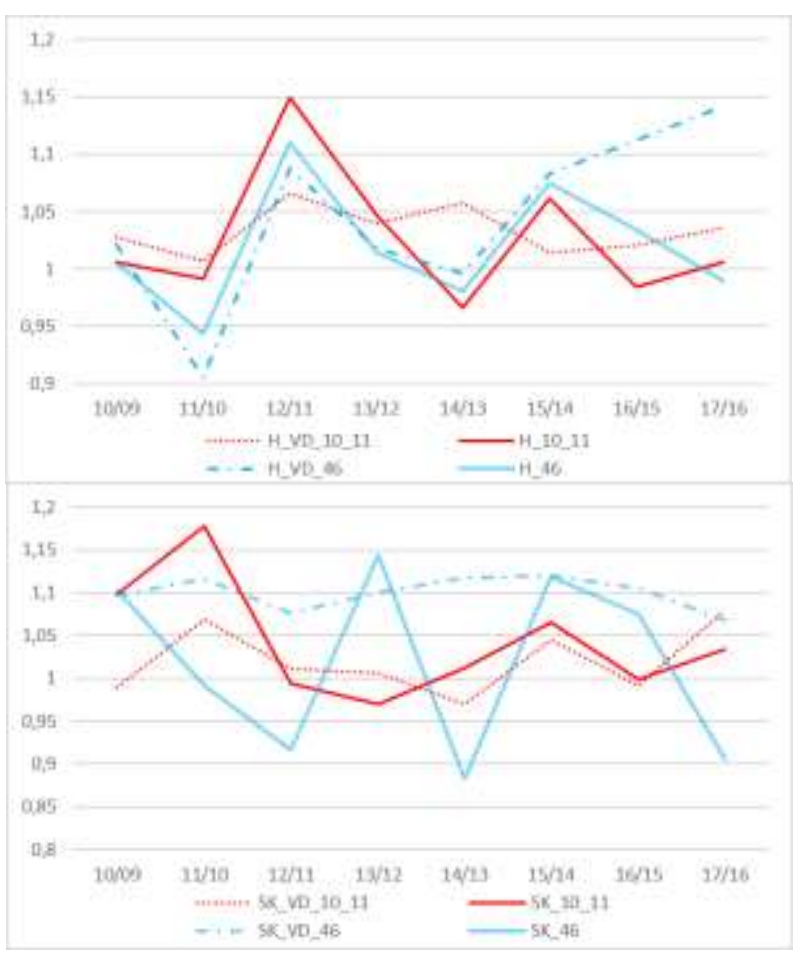

Figure 3.Year-on-year index of indicator operating expenditures (OPEX), comparing voluntary donors (VD) with industry average in the observed industries according to EU NACE divisions within the Visegrad 4 countries - Czechia (upper left graph), Hungary (upper right graph), Poland (lower left graph), Slovakia (lower right graph)

*Voluntary donors to food banks were not identified for EU NACE industry division 01 in Hungary, Poland, and Slovakia

A conducted dynamic decomposition analysis of the cost of sales with a focus on the sales side reveals the following findings among sample groups of donors to food banks in the Visegrad 4 member countries. The highest volatility of sales regarding food donors in EU NACE divisions 10-11 was observed within the period of years 2009-2017 among businesses based in Poland (variation coefficient reaching nearly $10 \%$, average yearon-year growth of sales above $12 \%$ ). Development of sales regarding food donors 


\section{Sciendo}

Management Theory and Studies for Rural Business and Infrastructure Development

eISSN 2345-0355. 2021. Vol. 43. No. 4: 442-456

Article DOI: https://doi.org/10.15544/mts.2021.40

active in EU NACE division 46 also points out the highest volatility among businesses based in Poland (variation coefficient at a height nearly $19 \%$, average year-on-year growth of sales above $10 \%$ ). In contrast to findings regarding donors to food banks based in

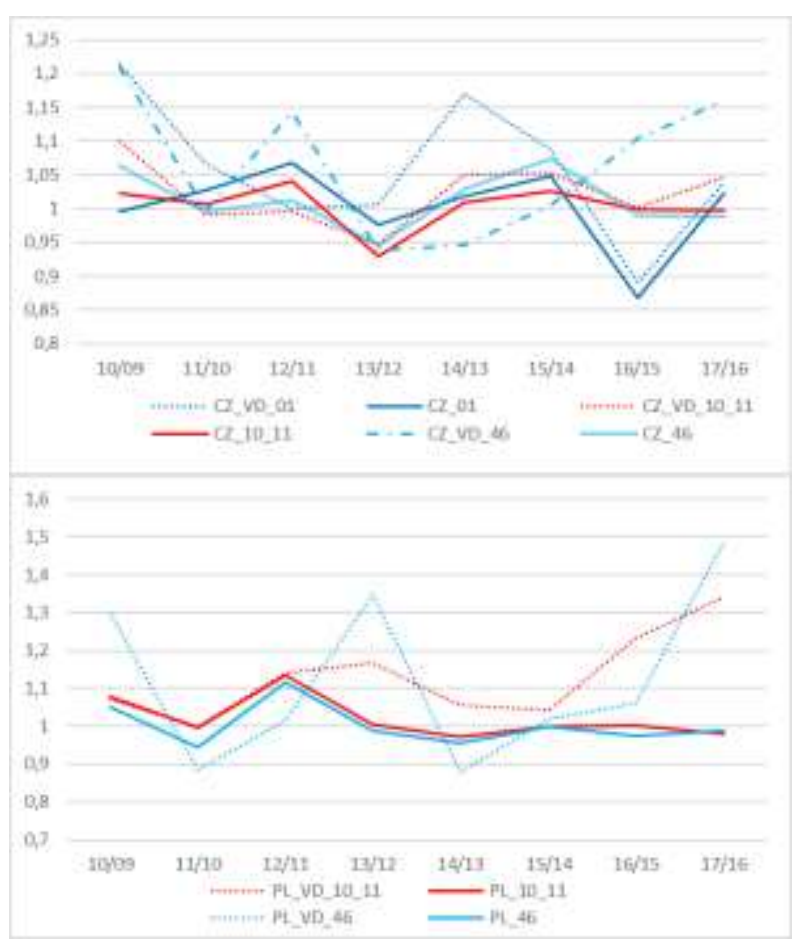

Poland, it could be stated the most stable development of sales regarding observed sample of EU NACE division 46 sample for the case of Slovakia (variation coefficient lower than $2 \%$, average year-on-year growth of sales at $10 \%$ ).

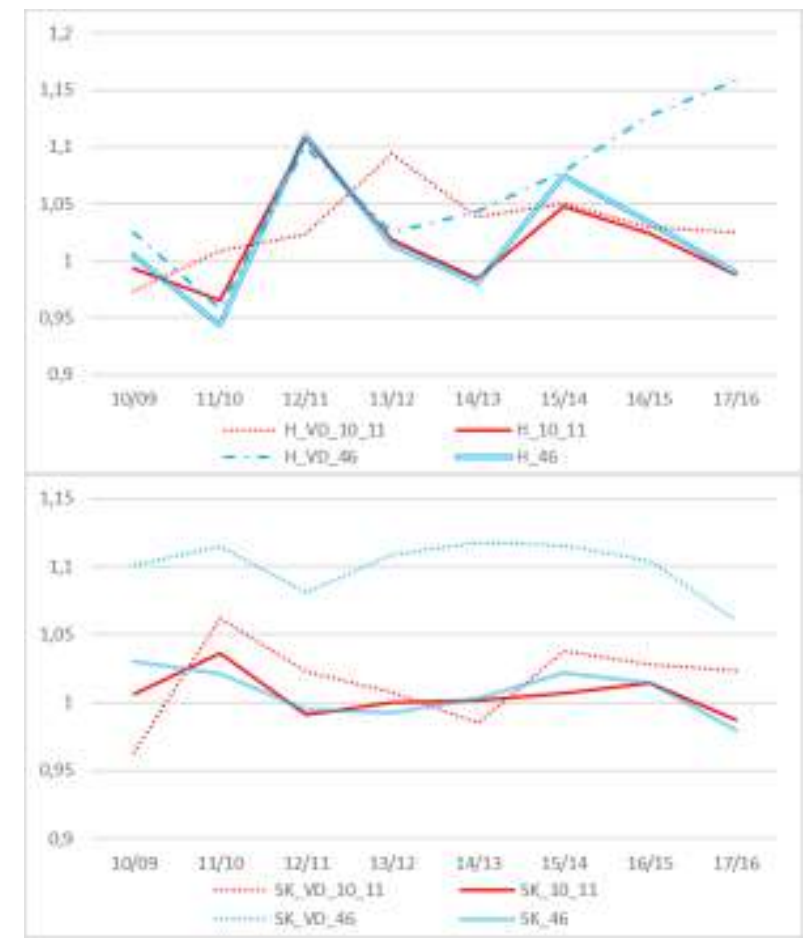

Figure 4. Year-on-year index of indicator sales, comparing voluntary donators (VD) with industry average in the observed industries regarding EU NACE divisions within the Visegrad 4 countriesCzechia (upper left graph), Hungary (upper right graph), Poland (lower left graph), Slovakia (lower right graph)

*Voluntary donors to food banks were not identified for EU NACE industry division 01 in Hungary, Poland, and Slovakia

Results of conducted correlation analysis of year-on-year indices of operating expenditures and sales development among voluntary donors within EU NACE divisions 10-11 (see Table 3) revealed a prevailingly strong or medium rate of positive mutual correlation with an exemption regarding the sample of donors based in Hungary. On contrary, it was identified a diverse development of operating expenditures with a higher average increase of operating expenditures over sales for the case of Hungarian donors to food banks within EU NACE division $10-11$ in the period of years 2009-2013. Subsequently, it was identified a higher average increase of operating expenditures over sales for the sample group of donors based in Poland in the period of years 2014-2017. Conversely, results of correlation analysis regarding EU NACE division 46 revealed only a strong positive correlation between the development of operating expenditures and sales among voluntary donors to food banks in the Visegrad 4 member countries (Hypothesis 2C rejected for the whole sample group of voluntary donors). This result differs from the observed industry average values that reports also a medium rate correlation of operating expenditures and sales. Finally, correlation analysis of operating expenditures for voluntary donors within EU NACE division 01 was conducted only for the 
Czech Republic. It is followed by the fact that the other Visegrad 4 member countries did not report any voluntary donors to food banks from the aforementioned EU NACE division. Voluntary donors from the sample group EU NACE division 01 are identified with a medium rate correlation of operating expenditures and sales. A lower level of correlation between operating expenditures and sales was then identified for the respective industry EU NACE division 01 average (Hypothesis 2A not rejected). Observations within EU NACE industry division group 1011 revealed only a weak positive correlation regarding voluntary donors to food banks based in Hungary (Hypothesis 2B not rejected). Additionally, for the case of Hungarian voluntary donors to food banks active in industry division group $10-11$ is stated about 1 PP higher average growth rate of operating expenditures in comparison with the average growth rate of sales in the observed period of years 2009-2017. This partial finding is consistent with an identified high-cost demandingness of sales in the observed industry.

The result for EU NACE division 01 meets the economic justification regarding the existence of agricultural subsidies in the EU. In addition, it was also identified a strong positive correlation for the observation of operating expenditures and sales within the EU NACE division 01 industry average in Poland. This finding fulfils the economic justification of specific national conditions for agricultural producers in comparison with other of the Visegrad 4 member countries (e.g. tax conditions for labour and enterprises in the Polish agricultural sector, mainly with enterprises of smaller economic size).

Table 3. Correlation coefficients regarding year-on-year development of operating expenditures and sales regarding sample groups of donors to foodbanks (VD) in the Visegrad 4 member countries and its comparison with industry averages (IA) in years 2009-2017

\begin{tabular}{|c|c|c|c|c|c|c|c|c|}
\hline \multirow{2}{*}{$\begin{array}{l}\text { EU } \\
\text { NACE } \\
\text { division }\end{array}$} & \multicolumn{2}{|l|}{$\mathbf{C Z}$} & \multicolumn{2}{|l|}{$\bar{H}$} & \multicolumn{2}{|l|}{$\mathbf{P L}$} & \multicolumn{2}{|l|}{ SK } \\
\hline & VD & IA & VD & IA & VD & IA & VD & IA \\
\hline $10-11$ & 0.665 & 0.475 & 0.167 & 0.901 & 0.905 & 0.715 & 0.716 & 0.722 \\
\hline 46 & 0.986 & 0.689 & 0.971 & 0.740 & 0.984 & 0.823 & 0.968 & 0.505 \\
\hline 01 & 0.795 & 0.490 & n.a. & 0.689 & n.a. & 0.938 & n.a. & 0.655 \\
\hline
\end{tabular}

The two-sided T-test was conducted in order to statistically prove possible significant differences in the cost of sales among observed samples voluntary within the Visegrad 4 countries. he summary of the T-test and related F-test statistics for variance are provided in Table 4.

Table 4. Two-sided two-sample T-tests statistics for equal (E) and unequal (U) variances and F-test for a variance of indicator cost of sales mean values regarding sample groups of voluntary donors and observed industry divisions benchmarks within the Visegrad 4 member countries (significance level alpha $=0.05$, $p$-values denoted in brackets)

\begin{tabular}{|c|c|c|c|c|c|c|c|c|}
\hline \multirow[b]{2}{*}{$\begin{array}{l}\text { EU NACE } \\
\text { division }\end{array}$} & \multicolumn{2}{|l|}{$\mathrm{CZ}$} & \multicolumn{2}{|l|}{$\mathbf{H}$} & \multicolumn{2}{|l|}{ PL } & \multicolumn{2}{|l|}{ SK } \\
\hline & $\begin{array}{l}\text { Two- } \\
\text { sample } \\
\text { T-test }\end{array}$ & F-test & $\begin{array}{l}\text { Two- } \\
\text { sample } \\
\text { T-test }\end{array}$ & F-test & $\begin{array}{l}\text { Two- } \\
\text { sample } \\
\text { T-test }\end{array}$ & F-test & $\begin{array}{l}\text { Two- } \\
\text { sample } \\
\text { T-test }\end{array}$ & F-test \\
\hline $10-11$ & $\begin{array}{l}\mathrm{tU}(9)= \\
-2.206 \\
(0.055)\end{array}$ & $\begin{array}{l}\mathrm{F}(8,8)= \\
15.488 \\
(<0.01)\end{array}$ & $\begin{array}{l}\mathrm{tU}(8)= \\
1.634 \\
(0.141)\end{array}$ & $\begin{array}{l}\mathrm{F}(8,8)= \\
51.415 \\
(<0.01)\end{array}$ & $\begin{array}{l}\mathrm{tU}(9)= \\
1.126 \\
(0.289)\end{array}$ & $\begin{array}{l}\mathrm{F}(8,8)= \\
21.528 \\
(<0.01)\end{array}$ & $\begin{array}{l}\mathrm{tU}(10)= \\
-5.153 \\
(<0.01)\end{array}$ & $\begin{array}{l}\mathrm{F}(8,8)= \\
7.266 \\
(<0.01)\end{array}$ \\
\hline 46 & $\begin{array}{l}\mathrm{tU}(9)= \\
-2.343 \\
(0.044)\end{array}$ & $\begin{array}{l}\mathrm{F}(8,8)= \\
30.854 \\
(<0.01)\end{array}$ & $\begin{array}{l}\mathrm{tU}(8)= \\
-4.670 \\
(<0.01)\end{array}$ & $\begin{array}{l}\mathrm{F}(8,8)= \\
48.789 \\
(<0.01)\end{array}$ & $\begin{array}{l}\mathrm{tU}(8)= \\
0.861 \\
(0.414)\end{array}$ & $\begin{array}{l}\mathrm{F}(8,8)= \\
2762.79 \\
0 \\
(<0.01)\end{array}$ & $\begin{array}{l}\mathrm{tE}(16)= \\
-10.623 \\
(<0.01)\end{array}$ & $\begin{array}{l}\mathrm{F}(8,8)= \\
0.900 \\
(0.443)\end{array}$ \\
\hline
\end{tabular}




\begin{tabular}{|c|c|c|c|c|c|c|c|c|}
\hline 01 & $\begin{array}{l}\mathrm{tE}(16)= \\
-3.329 \\
(<0.01)\end{array}$ & $\begin{array}{l}\mathrm{F}(8,8)= \\
1.991 \\
(0.350)\end{array}$ & n.a. & n.a. & n.a. & n.a. & n.a. & n.a. \\
\hline
\end{tabular}

Results of conducted T-tests proved at a $5 \%$ significance level prevailing statistically significant differences between observed indicator cost of sales, when comparing data samples of voluntary donors active in EU NACE division 46 (rejection of hypothesis 1C) with respective industry benchmarks among the Visegrad 4 member countries. However, there are identified different results in Poland for both observed EU NACE industry division group 10-11 and 46, regarding evidence of the cost of sales (not rejected hypothesis 1B and 1C). Subsequently, it has to be added that observed industry averages of indicator cost of sales in Poland belong to the lowest ones among the Visegrad 4 member countries. Hypothesis 1B was rejected regarding the sample of donors to food banks only in Slovakia that is proving the fact of prevailingly non-differing efficiency in placing goods on market among businesses based in most of the Visegrad 4 member countries. Additionally, hypothesis 1A regarding evidence on voluntary donors of plant and animal production could be tested only for the Czech Republic and this hypothesis was rejected.

These partial findings open up a discussion over the intention of donors to cooperate with food banks. These intentions need not be a pure philanthropy way of applying corporate social responsibility, but rather a good identification of possible synergy effect by managers of business entities in agrifood industry sectors. Namely, synergy effects, which are affecting the cost side of production and related logistic operations of products, specifically with a limited shelf life. In comparison, the food insecurity regarding the case of British households and the same vulnerable groups is also highlighted in the article of Loopstra et al. (2019). These authors draw attention to the fact that the operational characteristics are an important part of access to food banks and are connected with the ability of food banks to meet the needs of people at risk of food insecurity. With a smaller number of operating hours, the distribution centre was associated with a lower volume of use of food banks. From this fact it can be deduced that the volunteering system also contains its gaps, which lie in the possibilities of volunteers. They are limited by the need to ensure their livelihood and social relationships. Financial subsidies aimed at creating basic jobs for people, who expand the operational capabilities of food banks and charities, should not be a controversial topic in this context. Charitable activity is not enforceable and should not endanger the existence of the providers themselves. Food banks in the Visegrad Group countries are also operating with a strong dependency on volunteering and both civic and corporate willingness to take part in donation schemes. The unprecedented COVID-19 crisis enhanced the aforementioned weaknesses, which are causing a limited ability to address a more flexible response to an increase in demand for food banks' services, specifically then for the case of the Czech Republic.

Complementarily, Petrů, Kramoliš, \& Stuchlik (2020) broaden up the aforementioned problem area to the closer relationship of business entities with their customers, including a complex value-based approach that does not exclude their social corporate responsibility inclusion. Evidence from other European countries reveals a need for the adequacy of social policy as demonstrated by Loopstra et al. (2015) who identified that more food banks were opened in areas experiencing greater cuts in spending on local services and central welfare benefits and higher unemployment rates. Food parcel distribution is higher also in areas where food banks are more common and better established, but in that areas, the local authorities apply greater rates of sanctions which leads to people looking for emergency food assistance. Authors of the aforementioned 
research point out that food bank referrals are not always easy to obtain, so the utilization of data (e.g. the number of plots distributed) is an imperfect measure of need. The use of food banks across all providers even in the UK, that is regarded as a country with developed food banking schemes, is not closely monitored, leading to an underestimation of the true burden of food insecurity there. Our empirical findings on food banks in the Visegrad Group member countries point out misbalances in their operations as well. It is mainly argued within the one-way supplies of foodstuff from the production and distribution chain without further mutual information flow. This finding is consistent with Thompson et al. (2018), who draws attention to food safety, diversity and nutritional balance in the context of food poverty, which according to the research of their article should be minimized in the context of preventing the use of food banks as a cheap outlet to reduce disposal costs, or the obligation to transfer food to food banks in the suitable time conditions before its consumption.

Conversely, Garratt (2017) warns against the increasing reliance on emergency food, subsequent an unfolding public health crisis, and the need for the national surveillance system to monitor food insecurity and food bank use for the case of Great Britain. Additionally, it was further expanded these findings with outputs in the corporate management or corporate finance, as it is argued also e.g. by Belas, Strnad, Gavurov, \& Cepel (2019) regarding a need for focus on the complex determinants of the quality of the business environment. Similarly, it can be regarded the results of Chalastra, Kotapski, Kozubíková, \& Kozubík (2019) on the social responsibility context within approaches to valuation of business entities. Our findings in this article are consistent with the aforementioned findings specifically regarding a shallow way of monitoring the financial and non-financial effects and social impacts of services provided by food banks in selected CEE countries. This fact can be broadened to cost-benefit spillovers towards participating business entities, which are mostly overlooked considering the role of voluntary food donors.

\section{Conclusion}

The volume of food aid distributed by foodbanks is growing in the observed CEE countries also thanks to the public support for reconstructions and new constructions of food storage facilities, including technological equipment for food banks and other entities with a humanitarian focus. Tax incentives for producers and distributors to withdraw food from the market under certain conditions in favour of food banks and other charity types of entities should also be mentioned. A significant barrier to the effective operations of food banks can be seen in the lack of support for awareness-raising activities, resp. advisory support for operational activities that is not provided by government authorities. It can be proposed in the aforementioned context to enhance a public-private type of partnership among food banks charities and manufacturers and distributors on one hand and public authorities on the other hand. Such a partnership supported mainly by information/knowledge sharing can help to coordinate and fulfil national strategies on reducing the food poverty and simultaneously the food wastage.

Financial support of food banks by respective government authorities is currently indispensable for their activities, specifically then in the observed case of the Visegrad Group member countries, due to a need for subsidizing the operational area of food banks regarding the intended scope of their activities. Food banks also cannot operate without the participation of volunteer workers, who reduce the need to cover their personnel cost. Voluntary food donors can also contribute to the stated concept of food bank activities by active cooperation in supporting the governance of these food banking institutions. Thus, not only at the level of cost-free food provision, which in the vast majority of cases is donated by foodstuff retailers or producers as at the respective end-of-shelf-life of the foodstuff. Therefore, if not donated, such 
foodstuff would have to be disposed of in an environmentally sound manner (considering the cost side of disposals) to the detriment of the aforementioned voluntary food donors in the role of producers or distributors of the foodstuff. The need for active involvement of food producers and retailers in the operations of food banks and charities in the role of a relevant stakeholder can be promoted by indirect public support. Such active involvement of business entities and public awareness (e.g. in the form of possible tax base reduction) can help to diminish the demandingness of direct public financial support by food banks and charities in the field of food donations. This recommendation is consistent with our empirical findings behind the voluntary food donations of business entities in selected European countries as follows.

Our empirical findings regarding financial aspects behind voluntary donations to food banks within selected EU NACE industry divisions and respective donors' samples among selected CEE countries only partially prove statistically significant differences in selected financial measures, which were hypothetically expected among voluntary foodstuff donors and industry benchmarks. Concretely, voluntary donors active in the EU NACE industry division group 10-11 (manufacture of food products and nonalcoholic beverages) in the Visegrad 4 member countries, are identified as not differing in efficiency indicator cost of sales from industry average - not rejecting of hypothesis $1 \mathrm{~B}$ - only with the exemption of the sample of businesses representing the observed businesses based in Slovakia. Contrarily, we have identified the sample of businesses based in the Visegrad Group member countries, active in EU NACE industry division 46 (wholesale of food and non-alcoholic beverages), to be prevailingly differing from the industry average. Namely, the businesses with lover median values of the cost of sales - rejecting of hypothesis $1 \mathrm{C}$ - for the sample of voluntary donors group based in the Czech Republic, Hungary, and Slovakia. In addition, we have identified voluntary foodstuff donors within the EU NACE division 01 (plant and animal production) only in the Czech Republic, while concluding rejection of hypothesis $1 \mathrm{~A}$ for that case sample, proving a statistically significant difference in indicator cost of sales, when assessing foodstuff donors against the industry average. These aforementioned partial findings can be discussed both in terms of hypotheses testing and in terms of its results on selected financial indicators within observed periods and their dynamic decomposition. Our analysis revealed prevailingly a strong or moderate positive dependency within the development of indicators operating expenditures and sales for the sample group of voluntary foodstuff donors active in EU NACE industry division group 10-11, represented by businesses based in the Visegrad Group member countries, with the exemption of Hungary (not rejecting hypothesis 2B for the sample of foodstuff donors based in Hungary) due to a weak positive correlation of operating expenditures and sales in the observed period of years 20092017.

Subsequently, we have identified a strong positive correlation for the samples of voluntary foodstuff donors active in EU NACE industrial divisions 01 and 46 (plant and animal production, wholesale of food, and non-alcoholic beverages) within the observed development of their operating expenditures and sales. Our partial findings on the dynamic side regarding financial indicators of efficiency in placing production on market within the development of the sample of foodstuff donors in the Visegrad Group member countries point out above all at the cost side of business activities that can be considered as important influencing factors of competitiveness for the aforementioned industries. The case of the observed sample group of donors active in plant and animal production was then identified as the representative of an industry with long-term excessive dynamics of operating costs in comparison with the dynamics of sales. However, this finding is consistent with the principles of the EU Common Agricultural 
Policy subsidy schemes for compensation on the production cost side of respective agricultural producers.

Our empirical findings on voluntary donors to food banks, in comparison with other studies in that field, provide new specific insight on participating businesses entities and their intentions to donate foodstuff through corporate micro-financial data. Specifically, we argue via the empirical findings on foodstuff voluntary donors' financial data that voluntary donor activities need not to follow only philanthropy kind of motives to donate foodstuff in the case of business entities. On the other hand, the authors of this article admit the limitation of the current research outputs, as it is mainly in the absence of a survey on other non-financial influencing factors behind voluntary foodstuff donors' intentions, to participate as stakeholders of food banks in CEE countries.

Further research in this area is therefore necessarily considered to focus on possible measurement of the real societal effects on food donations of business entities to food banks and other charities via addressing its dead weight with a deductible overlap into the food security policy of the European Union.

\section{Acknowledgments}

This article was prepared as a partial output of a project financed by the Internal Grant Agency of FBE MENDELU in Brno, grant no. PEF_TP_2021004 "Sociální odpovědnost podniků jako podpurný nástroj změny systému financování potravinových bank v podmínkách ČR” [in Czech].

\section{References}

Belas, J., Strnad, Z., Gavurov, B., \& Cepel, M. (2019). Business Environment Quality Factors Research - SME Management's Platform. Polish Journal of Management Studies, 20, 64-77. https://doi.org/10.17512/pjms.2019.20.1.06.

Bureau van Dijk. (2019). - ORBIS [software]. - https://www.bvdinfo.com [2021 07 20].

Caraher, M., \& Furey, S. (2018). Title Growth of Food Banks in the UK (and Europe): Leftover Food for Leftover People. In The Economics of Emergency Food Aid Provision (pp. 25-48). Cham: Springer International Publishing. https://doi.org/10.1007/978-3-319-78506-6_2.

Chalastra, M., Kotapski, R., Kozubíková, Z., \& Kozubík, A. (2019). Human capital from the viewpoint of creating company value. Challenges for financial controllers. Management Sciences, 24(3), 3-9. https://doi.org/10.15611/ms.2019.3.01.

Eurostat. (2021). Eurostat Structural business statistics. - https://ec.europa.eu/eurostat/web/main/home. [2021 09 03].

Garratt, E. (2017). Please sir, I want some more: an exploration of repeat foodbank use. BMC Public Health, 17(1), 828. https://doi.org/10.1186/s12889-017-4847-x.

Gracjasz, A., \& Grasseni, C. (2020). Food-gifting in gdańsk: between food not bombs and the food bank. Ethnologia Polona, 41, 33-50. https://doi.org/10.23858/EthP41.2020.2018.

González-Torre, P., Lozano, S., \& Adenso-Díaz, B. (2017). Efficiency Analysis of the European Food Banks: Some Managerial Results. VOLUNTAS: International Journal of Voluntary and Nonprofit Organizations, 28(2), 822838. https://doi.org/10.1007/s11266-016-9814-0.

Ivanova, E., \& Cepel, M. (2018). The Impact of Innovation Performance on the Competitiveness of the Visegrad 4 Countries. Journal of Competitiveness, 10(1), 54-72. https://doi.org/10.7441/joc.2018.01.0.

Kuang, P. H., \& Chou, W. H. (2017). Research on Service Blueprint of Food Banks. The Design Journal, 20(sup1), S3425-S3435. https://doi.org/10.1080/14606925.2017.1352846.

Lipinski, B., Hanson, C., Waite, R., Searchinger, T., Lomax, J., \& Kitinoja, L. (2013). Reducing Food Loss and Waste.. - https://files.wri.org/s3fs-public/reducing_food_loss_and_waste.pdf. [2021 09 03].

Loopstra, R., Reeves, A., Taylor-Robinson, D., Barr, B., McKee, M., \& Stuckler, D. (2015). Austerity, sanctions, and the rise of food banks in the UK. BMJ, 350(apr08 9), h1775-h1775. https://doi.org/10.1136/bmj.h1775.

Loopstra, R., \& Lalor, D. (2017). Financial insecurity, food insecurity, and disability: The profile of people receiving emergency food assistance from The Trussell Trust Foodbank Network in Britain. https://www.trusselltrust.org/wp-content/uploads/sites/2/2017/07/OU_Report_final_01_08_online2.pdf. [2021 09 01].

Loopstra, Rachel, Lambie-Mumford, H., \& Fledderjohann, J. (2019). Food bank operational characteristics and rates of food bank use across Britain. BMC Public Health, 19(1), 561. https://doi.org/10.1186/s12889-019-6951-6.

Ministry of Agriculture of the Czech Republic. (2019). Ministerstvo zemědělství podporuje a i nadále bude podporovat potravinové banky. Ještě letos se bude snažit o navýšení finanční podpory. - 
http://eagri.cz/public/web/mze/tiskovy-servis/tiskove-zpravy/x2019_ministerstvo-zemedelstvi-podporuje-a-i.html. [2021 09 01]. [in Czech].

Nikolov, R. (2021). Waste Management Projections in Bulgaria, In Proceedings of Agribusiness And Rural Areas - Economy, Innovation And Growth 2021, Yogyakarta, August 25-26th 2021. https:// DOI:10.36997/ARA2021.325.

Petrovici, D. A., \& Gorton, M. (2005). An evaluation of the importance of subsistence food production for assessments of poverty and policy targeting. Food Policy, 30(2), 205-223. https://doi.org/10.1016/j.foodpol.2005.02.002.

Petrů, N., Kramoliš, J., \& Stuchlik, P. (2020). Marketing tools in the era of digitization and their Use in Practice by Family and other Businesses. E+M Ekonomie a Management, 23(1), 199-214. https://doi.org/10.15240/tul/001/20201-014.

Soon, J. M., Manning, L., Dani, S., Fassam, L., Jackson, E., \& Farag, K. (2016). Reduce surplus food: linking corporate donors and food banks.

https://www.researchgate.net/publication/318682855_Reduce_surplus_food_Linking_corporate_donors_and_food_ban ks. [2021 0901$]$.

Sosenko, F., Littlewood, M., Bramley, G., Fitzpatrick, S., Blenkinsopp, J., \& Wood, J. (2019). State of Hunger: A study of poverty and food insecurity in the UK. - https://www.stateofhunger.org/wp-content/uploads/2019/11/State-ofHunger-Report-November2019-Digital.pdf. [2021 09 01].

The Trussell Trust. (2021). Stop UK Hunger. - https://www.trusselltrust.org/about/. [2021 08 28].

Thompson, C., Smith, D., \& Cummins, S. (2018). Understanding the health and wellbeing challenges of the food banking system: A qualitative study of food bank users, providers and referrers in London. Social Science \& Medicine, 211, 95-101. https://doi.org/10.1016/j.socscimed.2018.05.030.

Wainwright, D., Buckingham, A., \& Wainwright, E. (2018). Why do people use food banks? A qualitative study of food bank users in an English city. Voluntary Sector Review, 9(3), 311-329. https://doi.org/10.1332/204080518X15428930047072. 